\title{
THE INHIBITION OF POLYISOPRENOIDS FROM NYPA FRUTICANS LEAVES ON CYCLOOXYGENASE 2 EXPRESSION OF WIDR COLON CANCER CELLS
}

\author{
DINI PERMATA SARI ${ }^{1}$, MOHAMMAD BASYUNI ${ }^{2 *}$, POPPY ANJELISA ZAITUN HASIBUAN ${ }^{1}$, RIDHA WATI ${ }^{2}$
}

${ }^{1}$ Department of Pharmacology, Faculty of Pharmacy, Universitas Sumatera Utara, Medan 20155, Indonesia. ${ }^{2}$ Department of Forestry, Faculty of Forestry, Universitas Sumatera Utara, Jl. Tri Dharma Ujung No. 1 Medan, North Sumatra, 20155, Indonesia. Email: m.basyuni@usu.ac.id

Received: 21 March 2018, Revised and Accepted: 23 April 2018

\section{ABSTRACT}

Objective: The objective of the study was to investigate the inhibitory activity of polyisoprenoids from Nypa fruticans leaves on the expression of cyclooxygenase 2 (COX-2) against colon cancer cells.

Methods: Anticancer activity performed was tested by dimethylthiazol-2-yl)-2,5-diphenyltetrazolium bromide method on colon cancer cell WiDr. The expression of COX-2 was observed by the immunocytochemistry method.

Result: Polyisoprenoids from $N$. fruticans leaves exhibit anticancer activity on WiDr cells throughinhibition of COX-2 expression with IC ${ }_{50} 180.186 \pm 7.16 \mu \mathrm{g} / \mathrm{ml}$

Conclusions: This study showed that polyisoprenoids from $N$. fruticans leaves promise chemopreventive agents for colon cancer through COX-2 inhibition.

Keywords: Cytotoxic, Polyisoprenoids, Nypa fruticans, Cyclooxygenase-2.

(C) 2018 The Authors. Published by Innovare Academic Sciences Pvt Ltd. This is an open access article under the CC BY license (http://creativecommons. org/licenses/by/4. 0/) DOI: http://dx.doi.org/10.22159/ajpcr.2018.v11i8.26098

\section{INTRODUCTION}

Cancer is one of the primary causes of death worldwide. Lung cancer, liver, stomach, colon, and breast cancer are the biggest causes of cancer deaths annually [1]. Colon cancer is the third most frequently diagnosed cancer-causing health problems and the fourth leading cause of cancer death worldwide. There is an increasing number of colon cancer patients each year. The incidence of colon cancer mainly occurs because it is influenced by socioeconomic level, behavior, and lifestyle [2]. Low physical activity and high fat consumption cause easy absorption of carcinogen compounds in the body and slow the transport time to the intestine which can lead to increased risk of colon cancer [3]. Increased incidence of colon cancer or colon cancer mortality was found in countries with low Human Development Index (HDI) levels, especially in Eastern Europe, Asia, and South America. On the contrary, the incidence of colon cancer and death from colon cancer has stabilized or decreased in a number of high HDI, such as the United States, Australia, New Zealand, and some countries in Western Europe [4].

Arachidonic acid metabolism is thought to play a significant role in the occurrence of carcinogenesis [5]. This metabolic pathway is associated with the formation of prostanoids. Prostanoids belong to the subclass of eicosanoids that convert to prostaglandins, thromboxane, and prostacyclin [6]. Cyclooxygenase (COX) is a critical enzyme in the conversion of arachidonic acid into prostaglandins [7].

The rapid development of the pharmaceutical industry in creating synthetic drugs currently aims to prevent and treat cancer, but most are toxic. Treatment technologies such as surgery, radiation, and chemotherapy are performed by administering anticancer drugs. This type of therapy makes patients experience nausea, vomiting, and hair loss [8]. Recommended companion therapy is the use of compounds that can reduce the effects of growth factors that may stimulate the rapid growth of cancer. Therapies aimed at enhancing the immune response to cancer also began to be widely tested in clinical studies. One component that has a high chance of being used in cancer therapy is medicinal plants [9]. Medicinal plants can be used for various functions and one of them as an inhibitor of COX-2 protein [10].

Mangrove has activity as a medicinal plant, and only a few have been explored [11]. Mangrove is famous for producing secondary metabolite compounds mainly from isoprenoid compound groups. The polyisoprenoids compound consists of two families, namely polyprenol and dolichol, polyprenol is known to have some pharmacological activity such as anticancer [12], antidyslipidemic [13], anti-influenza, and antiviral activity [14].

The distribution and diversity of polyisoprenoids compound in mangrove forests of Iriomote Island, Japan and North Sumatra, Indonesia have been reported by Basyuni et al. $[15,16]$. The promising mangrove species that potentially exhibit anticancer activity are Nypa fruticans [17]. However, the cytotoxic activity of polyisoprenoids from $N$. fruticans leaves on colon cancer cells with COX-2 as a target molecule is unclear. Therefore, this study aims to examine the cytotoxic activity of polyisoprenoids from $N$. fruticans leaves on high-frequency colon cancer cells expressing COX-2.

\section{METHODS}

Plants and isolation of polyisoprenoids

The sample used in this research is the leaves of $N$. fruticans obtained from the Lubuk Kertang Village, North Sumatera Province in February 2017. This plant is determined in Indonesia Institute of Science Research Center for Biology Bogor. A specimen voucher has been deposited there (No.354/IPH.1.01/If.07/IV/2017).

Preparation of polyisoprenoids from $N$. fruticans leaves was performed as described previously $[15,16,18]$. The leaves of $N$. fruticans were dried for 1-2 days at $60^{\circ} \mathrm{C}$ and then crushed to a powder. The leaves powder was extracted with mixture chloroform:methanol $(2: 1, \mathrm{v} / \mathrm{v})$ for $48 \mathrm{~h}$, then filtered and the remaining is a lipid extract in chloroform. The lipid extract in the chloroform of the leaves was saponified at $65^{\circ} \mathrm{C}$ 
for $24 \mathrm{~h}$ in $86 \%$ ethanol containing $\mathrm{KOH} 2 \mathrm{M}$. The unsaponifiable lipids were further dissolved with n-hexane, and the solvent was evaporated.

\section{Cell culture and conditions}

The WiDr cell used in this study is a collection of the Parasitology Laboratory of Gadjah Mada University, Jogjakarta, Indonesia. WiDr cells were grown in Roswell Park Memorial Institute 1640 (RPMI 1640) was purchased from Gibco (Carlsbad, CA, USA) containing FBS 10\% (v/v) was purchased from Sigma-Aldrich (St. Louis, MO, USA), penicillin antibiotics 100 units $/ \mathrm{ml}$ and streptomycin $100 \mu \mathrm{g} / \mathrm{ml}$ were purchased from Gibco (Carlsbad, CA, USA), phosphate buffer saline (PBS) was purchased from Sigma-Aldrich (St. Louis, MO, USA) and incubated in an incubator at $37^{\circ} \mathrm{C}, 5 \% \mathrm{CO}_{2}$.

\section{Cytotoxic test}

The cytotoxic activity of polyisoprenoids from $N$. fruticans leaves was performed according to the method of Mosmann [19] using a tetrazolium microculture (MTT) test method with 3-(4,5-dimethylthiazol-2-yl)-2,5diphenyltetrazolium bromide. The MTT powder was purchased from Sigma-Aldrich (St. Louis, MO, USA). The WiDr cells were distributed into 96 wells plate (Nunc) with a total of $5 \times 10^{3}$ cells per well and incubated with the test sample in various concentrations (15.625, $31.25,62.525,125,250$, and $500 \mu \mathrm{g} / \mathrm{ml}$ ) using DMSO solvent and incubated in incubator (Heraeus) for $24 \mathrm{~h}$ at $37^{\circ} \mathrm{C}$ with $5 \% \mathrm{CO}_{2}$. At the end of incubation, into each well was added $100 \mu \mathrm{L}$ MTT in RPMI 1640 medium. Then, the plate was incubated again for four $\mathrm{h}$ at $37^{\circ} \mathrm{C}$ with $5 \%$ $\mathrm{CO}_{2}$ until formed formazan crystals, see under an inverted microscope (Olympus, Tokyo, Japan). The living cells react with the MTT to form a purple color. After $4 \mathrm{~h}$, the MTT reaction was discontinued by adding $10 \%$ SDS reagent (Sigma-Aldrich, St. Louis, MO, USA) $100 \mu \mathrm{L}$ at each well then incubated overnight at room temperature covered by aluminum foil. Absorption is read by ELISA reader (Bio-Rad) at $595 \mathrm{~nm}$ wavelength.

Percent of inhibition is calculated based on the following equation:

Sample treatmentabsorbance-

$\%$ inhibition $=\frac{\text { Mediumabsorbance }}{\text { Untreated cellsabsorbance }-} \times 100$

Mediumabsorbance

The correlation between the percentage of inhibition and the concentration of polyisoprenoids from $N$. fruticans leaves was plotted, and $\mathrm{IC}_{50}$ was calculated through their interpolation through regression equation, $\mathrm{IC}_{50}$ was the concentration of polyisoprenoids from $N$. fruticans leaves inhibiting the growth of 50\% treated cells and cell morphology becomes abnormal.

Observation of COX-2 protein expression with immuno cytochemistry Analysis of inhibition of COX-2 protein expression using immunocytochemistry methods was performed as described previously by Galgano with slight modifications [20]. The WiDr cells were seeded on 24-wells plate, first included coverslip on each well. Cells were seeded with a density of $5 \times 10^{4}$ cells/well, incubated for $24 \mathrm{~h}$ at $37^{\circ} \mathrm{C}$ with $5 \% \mathrm{CO}_{2}$. Furthermore, the polyisoprenoids from $N$. fruticans leaves in various concentrations $(90,180 \mu \mathrm{g} / \mathrm{ml})$ were added to the cells and incubated for $24 \mathrm{~h}$ with $5 \% \mathrm{CO}_{2}$. The cells were washed with PBS. Then, cells were placed in the glass object for 5 min and added hydrogen peroxidase to the glass object and incubated at room temperature for 10-15 min. The cells washed twice with PBS and onto the glass object then added COX-2 monoclonal antibody (human anti-COX-2) (Santa Cruz Biotechnology, Dallas, TX, USA), and incubated $1 \mathrm{~h}$ at room temperature. The cells were washed 3 times with PBS, then added with secondary antibody (Biotinylated universal secondary antibody), and incubated at room temperature for $10 \mathrm{~min}$, and washed twice with PBS. As chromogen, added 3,3-diaminobenzidine, then incubated for 3-8 min. The cells were washed with distilled water and added hematoxylin solution and incubated for $5 \mathrm{~min}$ at room temperature.
The COX-2 expression was observed under light microscope and documented. Data were expressed as a percentage of cells expressing the COX-2 in 10 fields of view in each treatment group. The COX-2 expression appears brown in the cell nucleus and cytoplasm whereas cells without protein expression appeared purple.

\section{STATISTIC ANALYSIS}

Data were expressed as the mean \pm standard deviation of triplicate experimental value $(n=3)$. The analysis was performed using one-way ANOVA followed by Duncan's test differences for comparison between control and treatment groups. All statistical analyzes were performed using SPSS for Windows Version 23.

\section{RESULTS}

This study examined the cytotoxic effects of polyisoprenoids from $N$. fruticans leaves on colon cancer cell WiDr with an inhibitory observation on COX-2 protein. Cytotoxic effects were tested with MTT test, then measured the absorbance of formazan complex at a wavelength of $595 \mathrm{~nm}$ equivalent to the number of living cells. The results of the viability of colon cancer cells after administration of polyisoprenoids from $N$. fruticans leaves in various concentrations are shown in Fig 1. Polyisoprenoids from $N$. fruticans leaves $\left(\mathrm{R}^{2}=0.9158\right)$ showed cytotoxic activity in colon cancer cells WiDr depending on concentration. The $\mathrm{IC}_{50}$ value of polyisoprenoids from $N$. fruticans leaves was $180,186 \pm 7.16 \mu \mathrm{g} / \mathrm{ml}$.

The linear regression equation can be seen in the comparison graph with live cell percentage. From the results obtained, there is a decrease in the number of living cells based on the increased concentration given. Concentration $250 \mu \mathrm{g} / \mathrm{ml}$ has the best inhibition of cancer cell WiDr with a small percent of living cells. The polyisoprenoids from $N$. fruticans leaves obtained linear regression equation $Y=-0.4891 x+139.94$. From the derived linear regression can be calculated the $\mathrm{IC}_{50}$ value. The value of $\mathrm{IC}_{50}$ obtained from polyisoprenoids $N$. fruticans leaves is $180.186 \mu \mathrm{g} /$ $\mathrm{ml}$ from the calculation of concentration to live cells percentage.

Effect of polyisoprenoids from $N$. fruticans on COX-2 expression suppression

In this study, observation of protein suppression test of COX-2 has done by immunocytochemistry which then analyzed qualitatively and quantitatively. From the qualitative analysis, it shows that with increasing test extract levels, the positive COX-2 expressing cells are less, indicating that there has been a decrease in COX-2 expression in WiDr cells. Immunocytochemistry coloring results can be seen in Fig. 2 . Furthermore, quantitative analysis was done to find out the percentage emphasis of COX-2 protein expression by polyisoprenoids from $N$. fruticans leaves. Quantitative suppression of COX-2 expression is done by calculating the percentage of COX-2 expression. The results of the calculations can be seen in Table 1. In Table 1, it can be seen that the increasing concentration of polyisoprenoid from $N$. fruticans leaves of $90 \mu \mathrm{g} / \mathrm{ml}$ and $180 \mu \mathrm{g} / \mathrm{ml}$ and gives a decrease of COX-2. Expression pressure $36.83 \pm 2.01 \%$ and $16.42 \pm 2.86 \%$, respectively. While the average control of COX-2 suppression was $68.13 \% \pm 3.07$. It has been shown that administration of Polyisoprenoids from N. fruticans leaves $90 \mu \mathrm{g} / \mathrm{ml}$ inhibits Cox-2 protein expression. Similarly, administration of

Table 1: Number of cells that expressed COX-2

\begin{tabular}{ll}
\hline Treatment & \% Expression of COX-2 \\
\hline Untreated & $68.13 \pm 3.07$ \\
Polyisoprenoids from $N$. fruticans leaves & $36.83 \pm 2.01^{*}$ \\
$90 \mu \mathrm{g} / \mathrm{ml}$ & \\
Polyisoprenoids from $N$. fruticans leaves & $16.42 \pm 2.86^{*}$ \\
$180 \mu \mathrm{g} / \mathrm{ml}$ & \\
\hline
\end{tabular}

*Referred to the significant difference to untreated cells $(\mathrm{p}<0.05)$.

COX-2: Cyclooxygenase-2, N. fruticans: Nypa fruticans 


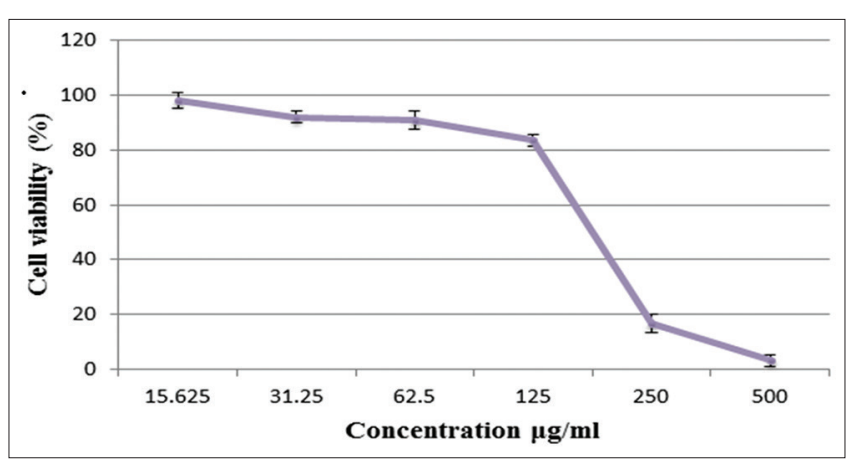

Fig. 1: Effect treatment of polyisoprenoids from Nypa fruticans leaves on colon cancer cells WiDr

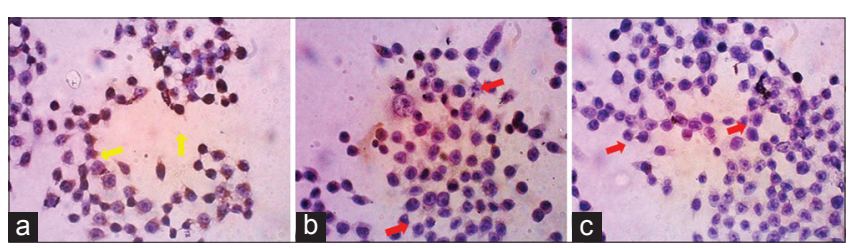

Fig. 2: Immunocytochemistry results of cyclooxygenase-2 (COX-2) on WiDr cells qualitatively. (a). The negative control, the group untreated with COX-2 specific antibody coloring. Visible all cells are brown, showing a positive result against COX-2. (b). Treatment of polyisoprenoids from Nypa fruticans leaves $90 \mu \mathrm{g} / \mathrm{ml}$. (c). Treatment of polyisoprenoids from $N$. fruticans leaves $180 \mu \mathrm{g} / \mathrm{ml}$ The yellow arrows showed the positive result of COX-2, the red arrow shows the negative result of COX-2. Observations under a light microscope with the magnification of $\times 40$

Polyisoprenoids from N. fruticans leaves $180 \mu \mathrm{g} / \mathrm{ml}$, shows that purple cells are clearer than controls. Furthermore, the percentage of COX-2 expression suppression data in each treatment and control group was statistically analyzed using one-way ANOVA parametric statistical analysis followed by Duncan's test. Statistical analysis showed that COX-2 protein expression suppression in various treatment and control groups gave significant difference $(p<0.05)$. The increase in the level of the given test extract was able to provide significantly increased percentage COX-2 expression when compared with the control.

\section{DISCUSSION}

This study evaluated the anticancer activity of polyisoprenoids from $N$. fruticans leaves on colon cancer cells WiDr. Polyisoprenoids from $N$. fruticans leaves tested against colon cancer cell WiDr have $\mathrm{IC}_{50}$ value $180.186 \pm 7.16 \mu \mathrm{g} / \mathrm{ml}$. The $\mathrm{IC}_{50}$ value in ranging from 100 to 300 is considered as a weak anticancer activity, whereas the $\mathrm{IC}_{50}$ value over than 300 is regarded as inactive compounds [21]. This suggests that polyisoprenoids from $N$. fruticans leaves have a potent cytotoxic effect on WiDr cells.

This study evaluated the anticancer activity of polyisoprenoids from $N$. fruticans leaves on colon cancer cells WiDr through inhibition of COX-2 expression. Many studies have been conducted both in vitro and in vivo on the activity of COX-2 inhibitors as cancer therapy $[22,23]$. The inhibition of COX-2 protein is an effective strategy to screen for chemopreventive agents in colon cancer [24]. Our results conclude that polyisoprenoids from $N$. fruticans leaves have anticancer activity in WiDr cells by inhibiting COX-2 expression. The results of this study support previous studies on the anticancer activity of $N$. fruticans leaves have cytotoxic effects on breast cells (MCF-7) and hepatocellular carcinoma (HepG2) [25]. N. fruticans leaves have been reported to contain polyisoprenoids, with majority dolichol compounds, no polyprenol detected [16]. Secondary metabolite compounds mainly from the group of isoprenoid also known as terpenoids, affect anticancer [26]. Terpenoids are compounds that have a high antitumor activity that has been tested through the ability to block nuclear factorkappa B, induce apoptosis, activate transcription, and angiogenesis. Although the mechanism of anticancer in colon cancer cells is unclear, terpenoids can be useful in the treatment of various types of cancer [27]. COX-2 inhibitory activity by polyisoprenoids from $N$. fruticans leaves with immunocytochemistry. The observed expression of COX-2 (Fig. 2) showed COX-2 expression due to polyisoprenoids treatment from $N$. fruticans leaves decreased compared to control. The inhibitory activity of COX-2 expression by polyisoprenoids from $N$. fruticans leaves may be due to inhibition of nuclear factor-kappa B. Terpenoids contained in $N$. fruticans leaves may inhibit NF- $\kappa B$ and Iк-B $\alpha$ [28]. This present results in a decrease of COX-2 expression.

COX-2 is an enzyme responsible for inflammatory response and prostaglandin production [29] and high expression in tumor cells [30]. Prostaglandins are reported to play a role in vascular endothelial growth factor upregulation and induce angiogenesis in tumor cells [31]. Thus, it is suspected that the activity polyisoprenoids from $N$. fruticans leave as anticancer is mediated by COX-2 inhibition as one of its mechanisms. The active compounds are primarily responsible for all these effects have not been further investigated, but it is suspected that the active compound was terpenoids. Terpenoids play a role in the regulation of the COX-2 expression [32]. Previous studies have shown similar relationships between terpenoids and anticancer effects [33,34]. The triterpenes and sterols were reported to exhibit antioxidant and anticancer properties [35]. The COX-2 expression assessment provides information on the prognosis and determines the treatment modalities. Treatment using COX-2 inhibitors can be done when in part encountered excessive COX-2 expression. The angiogenesis process as an indicator of the aggressiveness of some neoplasms is also essential in scores on the growth of colon cancer. Further research is needed to investigate the effects of polyisoprenoids from $N$. fruticans leaves in suppressing COX-2 expression. This experiment is expected to enrich the scientific evidence of polyisoprenoids activity from $N$. fruticans leaves as an anticancer, specifically to colon cancer.

\section{CONCLUSIONS}

Polyisoprenoids from $N$. fruticans leaves promise as a chemopreventive agent in colon cancer. Our data showed that polyisoprenoids from $N$. fruticans leaves inhibit expression of COX-2. Therefore, inhibition of COX-2 is one of the targeted therapy options developed for the treatment and prevention of cancer. Studies relating to the discovery of COX-2 inhibitor compounds still need to be developed to achieve maximum inhibitory effect but with minimal skill effect.

\section{ACKNOWLEDGMENT}

This study was supported by the Ministry of Research, Technology and Higher Education of the Republic of Indonesia through Excellent Research for Higher Education (PUPT) 2017 (No.003/SP2H/LT/ DRPM/IV/2017).

\section{AUTHOR'S CONTRIBUTION}

Collection of $N$. frutican leaves: DPS, MB, and RW. Performed the experiments and analyzed the data: DPS and RW. Draft preparation: DPS. Paper writing: DPS, MB, RW, and PAZH. All of the authors read and approved the final manuscript.

\section{CONFLICTS OF INTEREST}

The authors declare that they have no competing interests.

\section{REFERENCES}

1. Torre LA, Siegel RL, Ward EM, Jemal A. Global cancer incidence and mortality rates and trends-an update. Cancer Epidemiol Biomark Prev 2016;25:16-27.

2. Favoriti P, Carbone G, Greco M, Pirozzi F, Pirozzi RE, Corcione F. Worldwide burden of colorectal cancer: A review. Updates Surg 2016;68:7-11 
3. Aithal RR, Shetty RS, Binu VS, Mallya SD, Shenoy R, Nair S. Colorectal cancer and its risk factors among patients attending a tertiary care hospital in southern Karnataka, India. Asian J Pharm Clin Res 2017;10:109-12.

4. Arnold M, Sierra MS, Laversanne M, Soerjomataram I, Jemal A, Bray F. Global patterns and trends in colorectal cancer incidence and mortality. Gut 2016;1-9.

5. Pandev HP, Shukla HS, Prakash K, Tewari M, Pandey A, Singh AK. A discussion on chemoprevention of oral cancer by selective cyclooxygenase-2 (COX-2) inhibitors. Dig J Nanomater Biostruct 2010;5:285-95.

6. Geisslinger G, Schiffmann S, Maier, TJ, Grosh, S. Cyclooxygenase-2 (COX2) independent anticarcinogenic effect of selective COX-2 inhibitor. J Natl Cancer Inst 2006;98:736-47.

7. Wang D, DuBois RN. Prostaglandins and cancer. Gut 2006;55:115-22.

8. Demaria M, O'Leary MN, Chang J, Shao L, Liu S, Alimirah F, et al. Cellular senescence promotes adverse effects of chemotherapy and cancer relapse. Cancer Discov 2017;7:165-76.

9. Nassar ZD, Aisha AF, Idris N, Ahamed MB, Ismail Z, Abu-Salah KM, et al. Koetjapic acid, a natural triterpenoid, induces apoptosis in colon cancer cells. Oncol Rep 2012;27:727-33.

10. Dixon DA, Blanco FF, Bruno A, Patrignani P. Mechanistic Aspects of COX-2 Expression in Colorectal Neoplasia. Berlin, Heidelberg: Springer; 2013. p. 7-37.

11. Prasad N, Yang B, Kong KW, Khoo HE, Sun J, Azlan A, et al. Phytochemicals and antioxidant capacity from Nypa fruticans Wurmb fruit. J Evid Based Complement Alternat Med 2013;2013:1-9.

12. Kuznecovs S, Jegina K, Kuznecovs I. Inhibition of P-glycoprotein by polyprenol in human breast cancer cells. Breast 2007;16:515-21.

13. Singh G, Gupta P, Rawat P, Puri A, Bhatia G, Maurya R. Antidyslipidemic activity of polyprenol from Coccinia grandis in highfat diet fed hamster model. Phytomedicine 2007;14:792-8.

14. Safatov AS, Boldyrev AN, Bulychev LE, Buryak GA, Kukina TP, Poryvaev VD, et al. A prototype prophylactic anti-influenza preparation in aerosol form on the basis of Abies sibirica polyprenols. J Aerosol Med 2005;18:55-62

15. Basyuni M, Sagami H, Baba S, Iwasaki H, Oku H. Diversity of polyisoprenoid in ten Okinawan mangroves. Dendrobiology 2016;75:167-75

16. Basyuni M, Sagami H, Baba S, Oku H. Distribution and occurrence of new polyprenyl acetone and other polyisoprenoids in Indonesian mangroves. Dendrobiology 2017;78:18-31.

17. Prabhu VV, Devaraj SN. Natural products from mangrove potent inhibitors of lung cancer. Mal J Biosci 2016;3:23-30

18. Basyuni M, Wati R, Sagami H, Sumardi S, Baba S, Oku H. Diversity and abundance of polyisoprenoid composition in coastal plant species from North Sumatra, Indonesia. Biodiversitas 2018;19:1-11.

19. Mosmann T. Rapid colorimetric assay for cellular growth and survival: Application to proliferation and cytotoxicity assays. J Immunol
Methods 1983;65:55-63.

20. Galgano MT, Castle PE, Atkins KA, Brix WK, Nassau, SR, Stoler MH. Using biomarkers as objective standards in the diagnosis of cervical biopsies. Am J Surg Pathol 2010;34:1077.

21. Arsianti A, Fatmawaty F, Wibisono LK, Azizah NN, Putrianingsih R, Kusmardi S, et al. Phytochemical composition and anticancer activity of seaweeds Ulva lactuca and Eucheuma cottonii against breast MCF-7 and colon HCT-116 cells. Asian J Pharm Clin Res 2016;9:115-9.

22. Ahmed M, Hussain AR, Siraj AK, Uddin S, Al-Sanea N, Al-Dayel F, et al. Co-targeting of Cyclooxygenase-2 and FoxM1 is a viable strategy in inducing anticancer effects in colorectal cancer cells. Mol Cancer 2015;14:131

23. Yang H, Yin P, Shi Z, Ma Y, Zhao C, Zheng J, et al. Sinomenine, a COX-2 inhibitor, induces cell cycle arrest and inhibits growth of human colon carcinoma cells in vitro and in vivo. Oncol Lett 2016;11:411-8.

24. Ghosh N, Chaki R, Mandal V, Mandal SC. COX-2 as a target for cancer chemotherapy. Pharmacol Rep 2010;62:233-44

25. Samarakoon SR, Shanmuganathan C, Ediriweera MK, Piyathilaka P, Tennekoon KH, Thabrew I. Screening of fifteen mangrove plants found in Sri Lanka for in-vitro cytotoxic properties on breast (MCF-7) and hepatocellular carcinoma (HepG2). Eur J Med Plants 2016;14:1-11.

26. Huang M, Lu JJ, Huang MQ, Bao JL, Chen XP, Wang YT. Terpenoids: Natural products for cancer therapy. Exp Opin Investig Drugs 2012;21:1801-18.

27. Petronelli A, Pannitteri G, dan Testa U. Triterpenoids as new promising anticancer drugs. Pub Med 2009;20:880-92.

28. Appendino G, Maxia L, Bascope M, Houghton PJ, Sanchez-

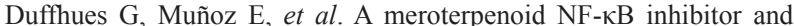
drimane sesquiterpenoids from asafetida. J Nat Prod 2006;69:1101-4.

29. Leahy KM, Ornberg RL, Wang Y, Zweifel BS, Koki AT, Masferrer JL. Cyclooxygenase-2 inhibition by celecoxib reduces proliferation and induces apoptosis in angiogenic endothelial cells in vivo.Cancer Res 2002;62:625-31.

30. Brown JR, DuBois RN. COX-2: A molecular target for colorectal cancer prevention. J Clin Oncol 2005;23:2840-55

31. Fukuda R, Kelly B, Semenza GL. Vascular endothelial growth factor gene expression in colon cancer cells exposed to prostaglandin E2 is mediated by hypoxia-inducible factor 1 . Cancer Res 2003;63:2330-4.

32. Wal P, Wal A, Sharma G, Rai A. Biological activities of lupeol. Sys Rev Pharm 2011;2:96-103

33. Kaur L, Joseph L, George M. Phytochemical analysis of leaf extract of Aesculus indica. Int J Pharm Pharm Sci 2011;3:232-4.

34. Soujanya J, Silambujanaki P, Krishna VL. Anticancer efficacy of Holoptelea integrifolia, Planch. against 7, 12-dimethyl benz (a) anthracene induced breast carcinoma in experimental rats. Int J Pharm Pharm Sci 2011;3:103-6.

35. Ragasa CY, Ebajo VD Jr., Mariquit M, Emelina H, Mandia RB, Urban S. Triterpenes and sterols from Sonneratia alba. Int J Curr Pharm Rev Res 2015;6:256-61 